\title{
Effects of Torrefaction Using COMB Dryer/Pyrolizer on the Properties of Rubberwood (Hevea brasiliensis) and Jabon (Anthocephalus cadamba) Pellets
}

\author{
W Hidayat ${ }^{1, *}$ T Rubiyanti ${ }^{1}$ Y Sulistio ${ }^{1}$, D A Iryani ${ }^{2}$, A Haryanto ${ }^{1}$, Amrul $^{2}, \mathrm{~J} \mathrm{Yoo}^{3}, \mathrm{~S}$ \\ $\mathrm{Kim}^{3}, \mathrm{~S} \mathrm{Lee}^{3}, \mathrm{U}_{\text {Hasanudin }}{ }^{*}$ \\ ${ }^{1}$ Faculty of Agriculture, University of Lampung, Bandar Lampung 35145, Indonesia \\ ${ }^{2}$ Faculty of Engineering, University of Lampung, Bandar Lampung 35145, Indonesia \\ ${ }^{3}$ Climate Change Research Division, Korean Institute of Energy Research, Daejon, 34129, Republic of Korea \\ *Corresponding author. Email: udinha@fp.unila.ac.id
}

\begin{abstract}
Rubberwood (Hevea brasiliensis) and Jabon (Anthocephalus cadamba) are two promising species that is widely planted in industrial plantation and community forests in Indonesia. The objective of this study was to improve the properties of rubberwood and jabon pellets through torrefacation. Torrefaction was performed at a temperature of $300^{\circ} \mathrm{C}$ and a residence time of $3 \mathrm{~min}$, using Counter-Flow Multi Baffle (COMB) Dryer/Pyrolizer. The properties of torrefied wood pellets as equilibrium moisture content (EMC), density, and heating value. Black pellets were succefully obtained after torrefaction using COMB Dryer/Pyrolizer. The EMC of the black pellets from rubberwood and jabon was $3.54 \%$ and $2.85 \%$, which is remarkably lower that their initial EMC of $12.25 \%$ and $12.76 \%$, for rubberwood and jabon pellets, respectively. The density of black pellets from rubberwood and jabon and decreased $16.18 \%$ and $13.44 \%$ compared to control. Torrefaction using COMB Dryer/Pyrolizer also increased high heating value of wood pellets to $18.32 \%$ and $79.70 \%$, for rubberwood and jabon pellets, respectively. Consequently, torrefaction using the COMB Dryer/Pyrolizer could improve the bioenergetic properties of jabon and rubberwood pellets.
\end{abstract}

Keywords: Torrefaction, Wood Pellets, Jabon, Rubberwood, COMB Dryer/Pyrolizer

\section{INTRODUCTION}

In Indonesia, plantation forests contribute a significant role in providing wood supply due to the declining productivity of the existing natural forests [1]. Wood supply from plantation forests reached 40.94 million $\mathrm{m}^{3}(85 \%)$ out of the total 47.96 million $\mathrm{m}^{3}$ in 2018 [2,3]. Indonesian plantation forests are dominated by fast-growing tree species such as rubberwood (Hevea brasiliensis) and jabon (Anthocephalus cadamba). Rubberwood is widely planted by the community to obtain latex as the main product [4], while jabon is widely planted due to its fast growth, with cutting cycles of 5 10 years [5].
Wood from plantation forests is generally inferior to wood from natural forests due to its relatively low durability, low density, and low strength that make it not suitable to be used for structural applications [6,7]. Forest industry sectors should be encouraged to adapt to the use of the species from planted forests, such as by converting it into biomass pellets. Biomass feedstocks are considered a renewable resource. However, biomass has several weaknesses compared to fossil fuels because it has high moisture content, lower in energy value and bulk density, high in mineral and oxygen contents, highly hygroscopic, and non-uniform in physical that make it difficult to handle $[8,9]$. 
Torrefaction is a promising technology to improve the biomass quality as fuel. Torrefaction is a thermal treatment that could overcome most of the issues related to biomass quality as fuel. Torrefaction is a thermochemical treatment of biomass that conducted at a temperature ranging between $200-300^{\circ} \mathrm{C}$ in a state of no oxygen, low heating rate with a residence time of 30 minutes up to 2 hours [10]. Torrefaction produces black pellets, solid fuel resembling coal, which has better fuel characteristics than the original biomass [8]. In this study, torrefaction was conducted using Counter-Flow Multi Baffle (COMB) Dryer/Pyrolizer that has simple, flexible, and movable baffles. Torrefaction using COMB Dryer/Pyrolizer could conducted within a short residence time $(\sim 5 \mathrm{~min})$ with low gas to solid ratio $(\mathrm{G} / \mathrm{S})$ and constant temperature difference (driving force) along the column. The objective of this study was to produce black pellet via torrefaction using COMB Dryer/Pyrolizer and imrpove the bioenergetic properties of rubberwood and jabon wood pellets.

\section{MATERIALS AND METHODS}

\subsection{Raw Material Preparation}

Rubberwood (Hevea brasiliensis) and jabon (Anthocephalus cadamba) wood pellets were sieved to separate fine dust. Jabon and rubberwood pellets had an average diameter of $6 \mathrm{~mm}$ and $8.5 \mathrm{~mm}$, respectively, and the length ranging between $17-24 \mathrm{~mm}$.

\subsection{Torrefaction Process}

Rubberwood and jabon wood pellets were torrefied using Counter Flow Multi-Baffle (COMB) Dryer/Pyrolyzer. The process parameters applied are as follow: temperature of $300^{\circ} \mathrm{C}$ and residence time of 3 minutes. The COMB Dryer/Pyrolyzer has a processing capacity of $20 \mathrm{~kg} / \mathrm{h}$, a maximum temperature of $500^{\circ} \mathrm{C}$, and a residence time of 3-5 min. The reactor has six main parts, namely: feeder, reactor column reactor, heat exchanger, burner, fine dust collector, and ID fan to circulate gas into the reactor (Fig. 1).

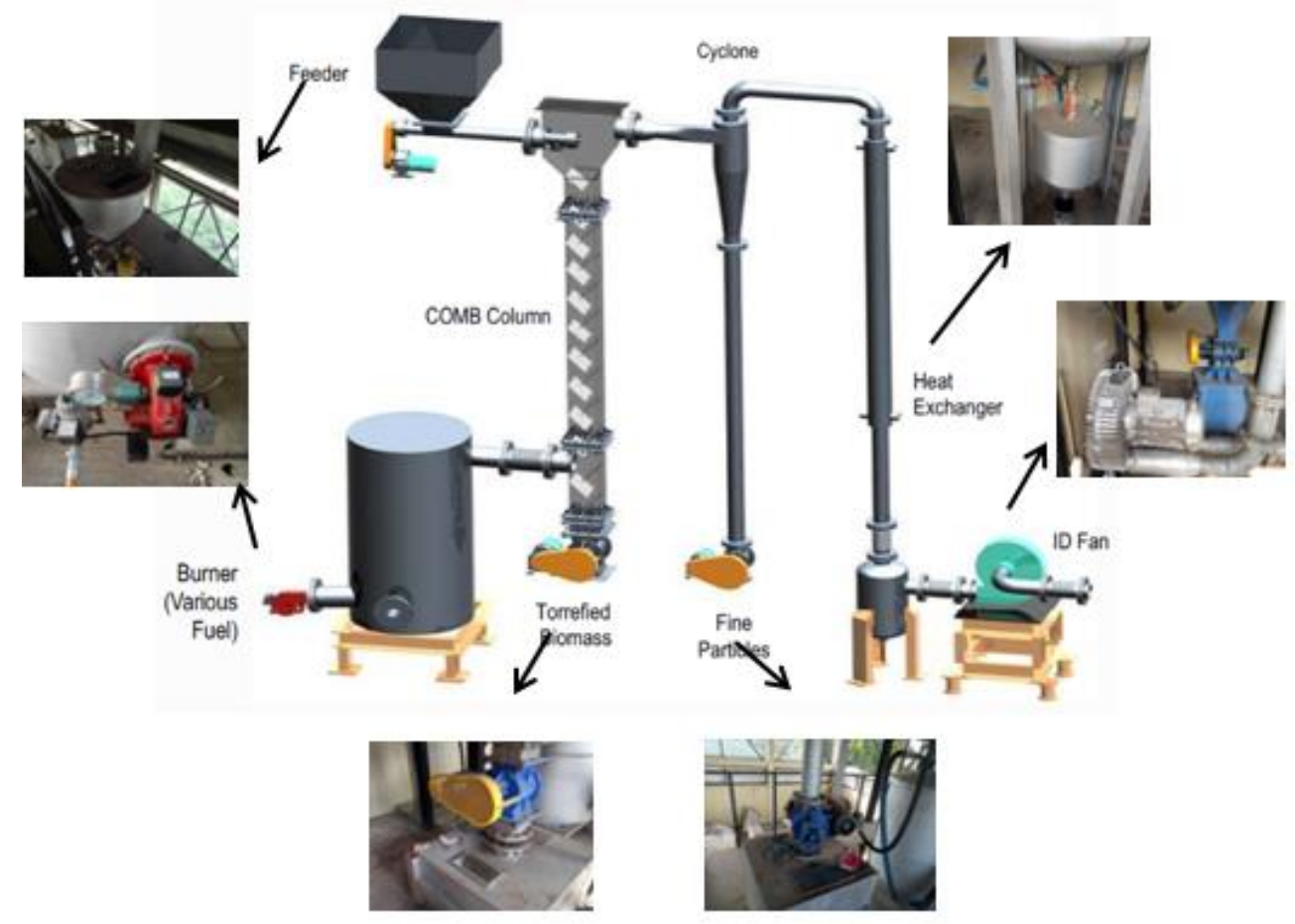

Figure 1. Counter Flow Multi-Baffle (COMB) Dryer/Pyrolizer

\subsection{Evaluation of the Properties of Wood Pellets}

The moisture content of samples was determined by measuring the air-dryweight and oven-dry weight of wood pellets using an analytical balance (Sartorius AZ6101, Göttingen, Germany) with a sensitivity of 0.01 $\mathrm{g}$. The density of samples was evaluated by measuring its air-dry weight and volume. The hygroscopic property was evaluated by immersing wood pellets into water and observe the visual changes that occurred after immersing for 1, 5, and 30 minutes, and 1, 2, 4, and 24 hours.
The chemical composition of raw and torrefied wood pellets was determined according to the method adapted from [11] with some modification. To determine the wax content of the sample, wood pellet was extracted in a soxhlet extractor over $8 \mathrm{~h}$ at $80^{\circ} \mathrm{C}$. The de-waxed sample of $150 \mathrm{mg}$ was then dried and put into a solution with 1.5 $\mathrm{ml}$ of $72 \mathrm{wt} \% \mathrm{H}_{2} \mathrm{SO}_{4}$ at $30^{\circ} \mathrm{C}$ for $1 \mathrm{~h}$. Water of $42 \mathrm{ml}$ was then added to the sample. The sample was then hydrolyzed in an autoclave at $121^{\circ} \mathrm{C}$ for $1 \mathrm{~h}$. After that, the sample was cooled, filtered, and then washed with hot water for several times. The residue, which is noted as 
Klason lignin (i.e., acid insoluble solid residue), was then dried at $105^{\circ} \mathrm{C}$ for $24 \mathrm{~h}$. The composition of a polysaccharide such as hemicellulose and cellulose was determined by using the method adapted from [11].

The heating value was measured by grinding wood pellets into powder. The powder was then dried in an oven-dryer at $100^{\circ} \mathrm{C}$ for $24 \mathrm{~h}$. Oven-dried powder of 0.5 $\mathrm{g}$ was used as a test sample. Measurement of the heating value was conducted using CAL2K ECO Milne Bomb Calorimeter.

\section{RESULTS AND DISCUSSION}

\subsection{Visual Appearance}

The visual appearance of rubberwood and jabon pellets before and after torrefied with COMB Dryer/Pyrolyzer is shown in Fig. 2. The color changes in the wood pellets after exposure to high temperatures can be mainly related to the change in chemical composition of biomass. Previous study [12] reported the severity of heat treatment at $160-220^{\circ} \mathrm{C}$ based on color coordinates $\left(L^{*}, a^{*}\right.$, and $b^{*}$ values, which represent lightness, red/green chromaticity, and yellow/blue chromaticity, respectively), showing the increase of color change $\left(\Delta E^{*}\right)$ with the increase of temperature, with the most visually noticeable change was the reduction in lightness $\left(L^{*}\right)$ or the darkening of biomasses. The reduction in $L^{*}$ values is related to the degradation of hemicelluloses during the process that attributed to the decrease of free hydroxyl groups and resulted in the increase of hydrophobicity of biomass [12-14]. Previous study [12] observed strong linear relationships between color change and hydrophobicity of biomass with a coefficient of determinations $\left(\mathrm{R}^{2}\right)$ values of 0.93 . The results in this study are in line with the above statements, showing the decrease of water absorbed (decrease of moisture content) with the increase of temperature or darkening of pellet color (Table 1).

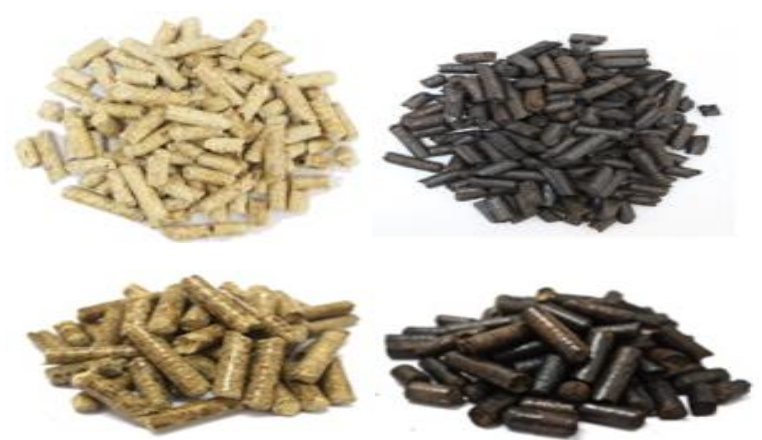

Figure 2. Rubberwood (top) and jabon (bottom) before torrefaction (left) and after torrefaction (right)

\subsection{Moisture Content and Density}

The initial moisture content (MC) of rubberwood and jabon pellets was $12.25 \%$ and $12.76 \%$ (Table 1). The values were within the range of equilibrium moisture content in Indonesia of $10-17 \%$ [15]. The MC of rubberwood and jabon pellets decreased up to $3.54 \%$ and $2.85 \%$ after torrefaction. Weight loss and volume shrinkage of the pellet that occurred during torrefaction resulted in the change of density, showing reduction of density after torrefaction.

Table 1. Moisture content and density of rubberwood and jabon pellets

\begin{tabular}{|c|c|c|c|c|c|}
\hline \multirow[t]{2}{*}{ Wood pellet } & \multirow{2}{*}{ MC (\%) } & \multicolumn{2}{|c|}{ Density $\left(\mathrm{g} / \mathrm{cm}^{3}\right)$} & \multicolumn{2}{|c|}{ Density reduction (\%) } \\
\hline & & Air dry & Oven dry & Air dry & Oven dry \\
\hline Rubberwood (control) & $12.25(2.30)$ & $1.29(0.05)$ & $1.15(0.05)$ & - & - \\
\hline Rubberwood (torrefied) & $3.54(1.22)$ & $0.99(0.09)$ & $0.96(0.10)$ & 22.71 & 16.18 \\
\hline Jabon (control) & $12.76(1.46)$ & $1.18(0.03)$ & $1.05(0.03)$ & - & - \\
\hline Jabon (torrefied) & $2.85(0.64)$ & $0.93(0.03)$ & $0.91(0.03)$ & 21.05 & 13.44 \\
\hline
\end{tabular}

The remarkable decrease of moisture content indicated that the biomass pellets became hydrophobic after torrefaction. The results of the water immersion test also showed the improvement in the hygroscopic behavior, showing fully disintegration of raw pellets after
$30 \mathrm{~min}$ in jabon and after $12 \mathrm{~h}$ in rubberwood pellets (Fig. 3 ). Black pellets of both kinds of wood showed no significant disintegration even after $24 \mathrm{~h}$ test, which is an advantage for long period storage of pellets. 


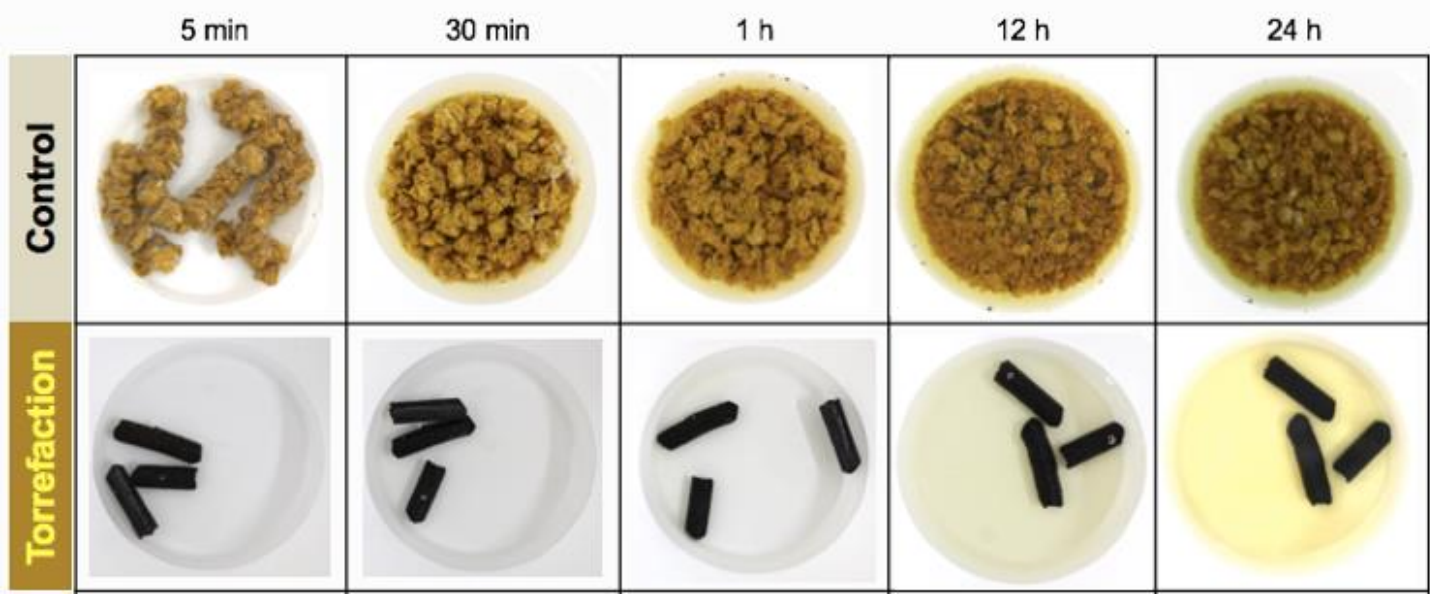

Figure 3. Water immersion test of the jabon pellets

\subsection{Chemical Composition and Heating Value}

Table 2 shows that the heating value of rubberwood and jabon raw pellets almost have the same values. Once they undergo torrefaction, their heating value was enlarged to $20.80 \mathrm{MJ} / \mathrm{kg}$ and $31.79 \mathrm{MJ} / \mathrm{kg}$. Jabon wood has a higher hemicellulose content compared to rubberwood. Due to their hemicellulose content more decrease than the other, the more pronounced the heating value of biomass enhanced from torrefaction. The hemicellulose was easier to be decomposed than other polymers due to its branched structure and a lower degree of polymerization [16].

Table 2. Elemental analyses, ash content, $\mathrm{O} / \mathrm{C}$ and $\mathrm{H} / \mathrm{C}$ atomic ratios, and heating value of control and torrefied pellets (\% wt d.b)

\begin{tabular}{|c|c|c|c|c|c|}
\hline \multirow{2}{*}{ Material } & \multicolumn{4}{|c|}{ Chemical composition (\%) } & \multirow{2}{*}{$\begin{array}{l}\text { Heating value } \\
\qquad(\mathrm{MJ} / \mathrm{kg})\end{array}$} \\
\hline & Cellulose & Hemicellulose & Lignin & Others & \\
\hline Rubberwood (control) & 43.13 & 13.59 & 30.11 & 13.17 & 17.58 \\
\hline Rubberwood (torrefied) & 42.29 & 7.64 & 38.78 & 9.95 & 20,8 \\
\hline Jabon (control) & 46.92 & 14.73 & 32.42 & 5.93 & 17.69 \\
\hline Jabon (torrefied) & 27.72 & 8.40 & 52.74 & 11.14 & 31.79 \\
\hline
\end{tabular}

\section{CONCLUSSIONS}

The torrefied pellets or the black pellets of rubberwood and jabon was successfully produced with excellent energy properties. The results showed the reduction of moisture content after the torrefaction of biomass pellets. The improvement in the hygroscopic behavior was also observed, showing a more hydrophobic product after torrefaction. The higher heating value of pellets remarkably increased after torrefed using COMB Dryer/Pyrolyzer. Consequently, COMB Dryer/Pyrolyzer could provide a significant improvement in the quality of wood pellets.

\section{ACKNOWLEDGMENT}

Authors acknowledge the Korea Institute of Energy Research (KIER) for financial support through Research Grant No. KIER 2019-0020.

\section{REFERENCES}

[1] Muhamad, S., Marwanto, Maulana, M.I., Maulana, S., Fatrawana, A., Hidayat, W., Sari, R.K., and Febrianto, F. 2019. Sifat Fisis dan Mekanis Papan Partikel Hibrida dari Kayu Cepat Tumbuh dan Bambu dengan Perlakuan Perendaman Panas. Jurnal Ilmu dan Teknologi Kayu Tropis. 17(1): 47-57

[2] MOEF-Ministry of Environment and Forestry. 2019. Statistics of Environment and Forestry 2018. Indonesia Ministry of Environment and Forestry. https://www.menlhk.go.id//site/download_file?file= 1574407944.pdf

[3] Utama, R. C., Febryano, I. G., Herwanti, S., and Hidayat, W. 2019. Saluran Pemasaran Kayu Gergajian Sengon (Falcataria moluccana) pada Industri Penggergajian Kayu Rakyat di Desa Sukamarga, Kecamatan Abung Tinggi, Kabupaten 
Lampung Utara. Jurnal Sylva Lestari 7(2): 195-203. DOI: 10.23960/js127195-203

[4] Febrianto, F., Hwee, S. P., Man, C. K., and Hidayat, W. 2017. Properties Enhancement of Rubber Wood Particleboard Laminated with Low Density Polyethylene (LDPE) Resin. Jurnal Ilmu dan Teknologi Kayu Tropis 10(2): 186-194.

[5] Hadiyane, A., Dungani, R., Dewi, S.P. Rumidatul, A. 2018. Effect of Chemical Modification of Jabon Wood (Anthocephalus cadamba Miq.) on Morphological Structure and Dimensional Stability. Journal of Biological Sciences. 18(4): 201-207. DOI: 10.3923/jbs.2018.201.207

[6] Febrianto, F., Pranata, A. Z., Septiana, D., Arinana, Gumilang, A., Hidayat, W., Jang, J. H., Lee, S. H., Hwang, W. J., and Kim, N. H. 2015. Termite Resistance of the Less Known Tropical Woods Species Grown in West Java, Indonesia. Journal of the Korean Wood Science and Technology 43(2): 248-257. DOI: 10.5658/WOOD.2015.43.2.248

[7] Hidayat, W., Qi, Y., Jang, J. H., Febrianto, F., Lee, S. H., Chae, H. M., Kondo, T., and Kim, N. H. 2017. Carbonization Characteristics of Juvenile Woods from Some Tropical Trees Planted in Indonesia. Journal of the Faculty of Agriculture, Kyushu University 62(1): 145-152

[8] Chen, W.H., Peng, J., dan Bi, X.T. 2015. A State-ofthe-Art Review of Biomass Torrefaction, Densification and Applications. Renewable and Sustainable Energy Reviews. 44: 847-866.

[9] Hidayat, W., Rani, I.T., Yulianto, T., Febryano, I.G., Iryani, D.A., Hasanudin, U., Lee, S.H., Kim, S.D., Yoo, J.H., and Haryanto, A. 2020. Peningkatan Kualitas Pelet Tandan Kosong Kelapa Sawit melalui Torefaksi Menggunakan Reaktor Counter-Flow Multi Baffle (COMB). Jurnal Rekayasa Proses. 14(2): 169-181

[10] Acharya, B., Sule, I., and Dutta, A. 2012. A Review on Advances of Torrefaction Technologies for Biomass Processing. Journal of Biomass Conversion and Biorefinery. 2: 349-369. DOI: 10.1007/s13399012-0058-y

[11] Datta, R. 1981. Acidogenic Fermentation of Lignocellulose-Acid Yield and Conversion Of Components, Biotech. and Bioeng. 23(9): $2167-$ 2170.

[12] Hidayat, W., Qi, Y., Jang, J.H., Febrianto, F., Lee, S.H., and Kim, N.H. 2016. Effect of treatment duration and clamping on the properties of heattreated okan wood. Bioresources. 11(4): 1007010086.

[13] Hidayat, W., Qi, Y., Jang, J.H., Park, B.H., Banuwa, I.S., Febrianto, F., and Kim, N.H. 2017. Color
Change and Consumer Preferences towards Color of Heat-Treated Korean White Pine and Royal Paulownia Woods. Journal of the Korean Wood Science and Technology. 45(2): 213-222.

[14] Hidayat, W., Qi, Y., Jang, J.H., Febrianto, F., Lee, S.H., and Kim, N.H. 2016. Effect of Treatment Duration and Clamping on the Properties of HeatTreated Okan Wood. BioResources. 11(4): 1007010086.

[15] Coto, Z. 2005. Reducing Equilibrium Moisture Content and Improving Dimensional Stability of Wood through Heating and Restraining. Jurnal Ilmu dan Teknologi Kayu Tropis. 3(1): 27-31.

[16] Iryani, D.A., Kumagai, S., Nonaka, M., Sasaki, K., Hirajima, T. 2017. Characterization and production of solid biofuel from sugarcane bagasse by hydrothermal carbonization. Waste Biomass Valor. 8:1941-1951. 